\title{
Infectious agents in juvenile scleroderma
}

\author{
Iryna Chyzheuskaya ${ }^{1,2^{*}}$, Lyudmila Belyaeva', Rostislav Filonovich², Larisa Zaitseva², Alexander Lyatun ${ }^{3}$ \\ From 21st European Pediatric Rheumatology (PReS) Congress \\ Belgrade, Serbia. 17-21 September 2014
}

\section{Introduction}

The problem of juvenile scleroderma (JS) is determined by a variety of clinical manifestations, tendency to early generalized process with the development of peripheral and visceral lesions. In the last decade various forms JS associated with Borrelia infection, as evidenced by the discovery of a skin biopsy patients spirochete Borrelia Burgdorferii afzelii, garinii and the presence of specific antibodies in the blood of patients. Besides bacterial relevant theory and molecular "mimicry" the herpes viruses, providing a provocative role in the development of JS.

\section{Objectives}

To determine the role of infectious factors in the genesis of juvenile scleroderma.

\section{Methods}

65 children with juvenile scleroderma were examined. Patients were divided into 2 groups: 41 patients with scleroderma (S) (mean age 13,1 $\pm 0,4$ years) and 24 with systemic sclerosis (SS) (mean age 12,7 $\pm 0,5$ years). All patients underwent bacteriological examination with nasopharyngeal flora definition of sensitivity to antibiotics. Antibodies in the blood was determined by Borrelia burgdorferi, Chlamydia psittaci, Herpes Simplex Virus Types 1, 2 and Cytomegalovirus. The concentration of interferon-gamma (IFN- $\gamma$ ) in the serum was determined by ELISA using kits from Immunotech (France).

\section{Results}

The most of children with the S (56.1\%) and SS (87.5\%) had chronic foci of infection (chronic tonsillitis, chronic pharyngitis, adenoids, chronic periodontitis). Staphylococcus aureus was allocated from the nasopharynx in $19.5 \%$ of patients with S and $25 \%$ of children with SS,

\footnotetext{
${ }^{1}$ Pediatrics, Belarusian Medical Academy of Postgraduate Education, Minsk, Belarus

Full list of author information is available at the end of the article
}

$\beta$-hemolytic streptococcus was allocated from $17.1 \%$ of children with S and in $30.8 \%$ of the SS. Antibodies to Borrelia burgdorferi in blood serum identified in 39.1\% of children with S and $37.5 \%$ of children with SS. Antibodies to Chlamydia psittaci in blood serum identified in $12.2 \%$ of patients with S and $16.7 \%$ of the SS.

The presence of chronic CMV infection revealed in $17 \%$ of children with the S and $20.8 \%$ of the SS. The presence of the herpes simplex virus infection revealed in $14.6 \%$ of patients with S and $25 \%$ with SS. Level of IFN- $\gamma$ in serum was significantly lower in all children with $S$ and SS than in healthy children $(0,76 \pm 0,2 \mathrm{pg} / \mathrm{ml})$. Reduction of IFN- $\gamma$ plays a role in reducing the antiviral immunity and confirmed the role of RNA viruses in the development and progression of juvenile scleroderma.

\section{Conclusion}

The foci of chronic infection alter the reactivity of the organism causing an imbalance in the immune system of children, and is likely to play a pathogenetic role in the occurrence of juvenile scleroderma. The presence of persistent viral infection and a significant decrease of IFN- $\gamma$ in children with SS and S suggests a role of viral infection in the development and progression of juvenile scleroderma.

\section{Disclosure of interest}

None declared.

\section{Authors' details}

${ }^{1}$ Pediatrics, Belarusian Medical Academy of Postgraduate Education, Minsk, Belarus. ${ }^{2} 4$ th City Children's Hospital, Minsk, Belarus. ${ }^{3}$ belarusian Medical Academy of Postgraduate Education, Minsk, Belarus.

Published: 17 September 2014
doi:10.1186/1546-0096-12-S1-P306

Cite this article as: Chyzheuskaya et al:: Infectious agents in juvenile scleroderma. Pediatric Rheumatology 2014 12(Suppl 1):P306.
C Biomed Central

(c) 2014 Chyzheuskaya et al; licensee BioMed Central Ltd. This is an Open Access article distributed under the terms of the Creative Commons Attribution License (http://creativecommons.org/licenses/by/4.0), which permits unrestricted use, distribution, and reproduction in any medium, provided the original work is properly cited. The Creative Commons Public Domain Dedication waiver (http://creativecommons.org/publicdomain/zero/1.0/) applies to the data made available in this article, unless otherwise stated. 